\title{
Church planting in South Africa: The role of the Reformed Church Tshiawelo
}

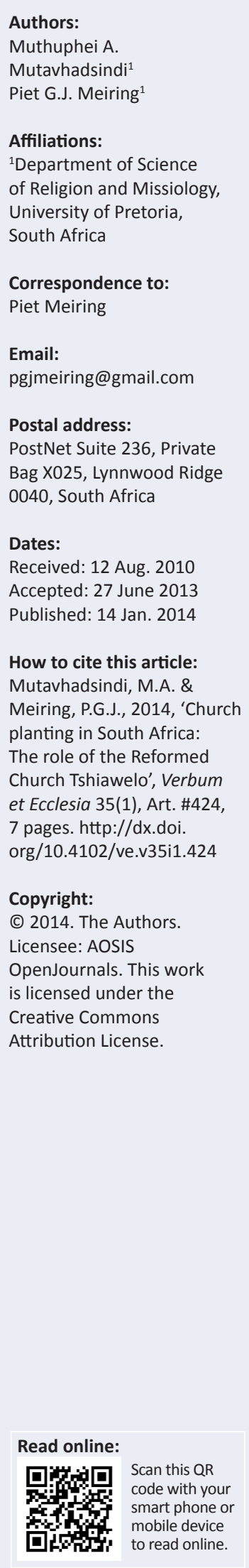

The Reformed Congregation of Tshiawelo, in Soweto, South Africa, has undergone a profound change over the past 20 years. It has developed from an ailing introverted church to a congregation that reached out to the wider community, increasing its membership dramatically in the process. In this article, the authors reported on a number of issues related to this transformation, including: the importance of partnerships in the process of renewal, the methodology used in the process of renewal, the need for church planting and the necessity for future planning.

\section{Introduction}

\section{Urbanisation: A challenge to the Church}

The spectacular growth of cities on this planet during the past century represents an awesome challenge to the Church of Jesus Christ on all six continents. The process is unstoppable and the Church must adjust itself to the new situation, taking responsibility to use the opportunities God is giving us to be witnesses to Christ in cities and towns all over the world - in our case, in Africa. The Church must see this process as a way for God to bring people together from different countries, languages, races and backgrounds to the South African cities, to be reached with the Gospel of our Lord Jesus Christ. Urbanisation is a serious challenge to the churches and requires that their mission must be seen in a new perspective: now as one not aimed at crossing the oceans, jungles and deserts, but as crossing the streets of our cities. South Africa is one of the African countries currently experiencing tremendous growth, inter alia as a result of the influx of many immigrants from African countries, from Europe, Asia and all over the globe. Immigrants are not always welcome in a new country and South Africa has not been immune to xenophobia in the past. We, however, must look at immigrants - as is the case with all people in need - with the eyes of our God. The more they come to South Africa, the greater the harvest for the Church.

Many younger churches in Africa, especially in South Africa, are awakening to their missionary obligation, of moving from the position of being receiving churches to becoming sending churches in their own right. We would like to argue that with a proper understanding of the biblical mandate for mission, especially for urban mission, as well as a firm grasp of the urban context within which the church has to function, a comprehensive strategy for mission in the cities of Africa may be developed. In the growing cities of the continent, the churches need to be informed and empowered to play their part. One of these churches, the Reformed congregation of Tshiawelo, was the subject of the first author's PhD thesis, conducted at the University of Pretoria. This present article stems from the interesting information on the role of Christians in urban mission, and on the methodology that may be developed to enable churches to be witnesses of Christ in this specific context, which came to the fore during the first author's research.

\section{The establishment and renewal of the Reformed Church Tshiawelo}

The Reformed Church Tshiawelo (RCT) congregation is located in Soweto, south-west of Johannesburg, in Gauteng Province, South Africa. The congregation was established by missionaries from the Reformed Churches in South Africa (RCSA) more than 40 years ago, in 1968 (RCSA 2005a:4). This church was formed by both newly converted believers from around the Soweto area who became Christians as a result of the work of the missionaries, as well by members of other churches who were attracted to the RCT.

Since its inception in 1968, the Tshiawelo congregation has faced many challenges. The new members were poorly equipped and unable to contribute to the maintenance of the church, leaving the RCT to rely heavily on the Soutpansberg Synod, of which it forms part, for all her activities. When the Soutpansberg Synod, in turn, found itself unable to fulfil all the expectations of the RCT mission church, a number of local leaders left the congregation to join other Soweto churches. 
After a slow start and an equally slow growth period mainly as a result of a lack of leadership and of vision, which caused the congregation to turn inward and, over the years, to become despondent - the church council and the members of the congregation, at the turn of the century, embarked on a rebuilding and revitalising programme for the church, in partnership with the RCT's mother body, the Synod of Soutpansberg. A number of important issues were raised in the process and valuable lessons were learned by the RCT over the last 20 years - the first of which being that no church can embark on the road to renewal on her own. Hence, this article seeks to explore these insights, in relation to the methodology enacted by the first author during his $\mathrm{PhD}$ research, in order to highlight the importance of the urban renewal process for churches wishing to actively engage with a growing urban population in South Africa and around the world.

\section{The many faces of partnership The Reformed Church Tshiawelo and the Synod Soutpansberg}

Every church needs partners. Within world Christianity, 'partnership' expresses a relationship between churches based on trust, mutual recognition and reciprocal interchange. It rules out the notion of 'senior' and 'junior', 'parent' and 'child', or even 'older' and 'younger'. It is a term designed to show that the different parts of the Church belong to one another, and find their fulfilment through sharing in a common life. It implies a relationship in which two or more bodies agree to share responsibility for one another, and in which each side meaningfully participates in planning the future of the other (Kirk 1999:184). In the New Testament, reference is often made to the concept of koinonia. According to Kirk (1999:188), the most basic meaning of the word is 'partaking together in a group which has a common identity, goals and responsibilities'. This was the type of partnership that existed between the RCT and the Synod Soutpansberg, a partnership that had great impact on the mission of the church in Soweto.

Partnership, koinonia, in the years between 1968 and 1990 in the context of South Africa, where apartheid was in full swing, was very difficult - and very necessary. Apartheid legislation made it extremely difficult for Black people to find permanent residence in the cities of South Africa and to minister to the inhabitants of Black townships who had no permanent address was an arduous process. Newly planted churches faced many problems. Most of their resources came from outside, from the missionaries, and the members of the new churches relied on the missionaries for virtually everything: for the ministers' salaries, for church maintenance, as well as for material support (food and clothes) for congregants. This seriously dented the independence and the self-confidence of the Black churches. When the missionary churches that increasingly had to face financial challenges in their own communities, were forced to withdraw their support, it created a new set of crises in the life of the young churches.
That is what happened to the RCT. Many church members, because of the dire poverty they experienced on a daily basis, found themselves unable to tithe. Other members declined, to protest the withdrawal of support by the missionary churches. It was during this time in the mid -1990s that Professor T.C. Rabali arrived at Tshiawelo from the Soutpansberg region in Limpopo Province, to help the young congregation in her moment of need. For a number of years after that, an agreement existed between the Reformed Church Mutale (where Prof. Rabali was ministering) and the RCT to work together. In 2005, the Mutale congregation, in a spirit of koinonia, decided to send Prof. Rabali to Tshiawelo, to work in the congregation as their gift and as their emissary. Because of this relationship between the two churches, it was easy for the RCT to enter into partnership with the other churches that comprise the Soutpansberg Synod as well.

\section{Partnership in urban mission}

According to J. Andrew Kirk (1999:187), partnership in mission belongs to the essence of the Church: partnership is not so much about what the Church does as about what it is. Churches, as the New Testament teaches us, belong to one another, for God has called each into the fellowship (koinonia) of his Son, Jesus Christ our Lord (1 Cor 1:9). In March 1998, the church councils of the churches that constitute the Synod Soutpansberg, together with the church council of the RCT, held an important leadership conference at Tshipise, in Limpopo Province. The conference was well attended by almost all church council members of the congregations that constitute the Synod Soutpansberg, ${ }^{1}$ as well as by church council members of the RCT. The conference was led by Prof. Rabali and the main theme of the conference was: Tshivhumbeo tshashu sa Kereke ri tshi pfuka nwaha wa 2000, which means 'Our structure as a church when we pass the year 2000'. The conference was a wake-up call for the congregations to prepare for the year 2000 and beyond (Rabali 1998:16). During that conference, the church council members came to a new understanding of the necessity of urban church planting, in their case especially in Gauteng Province. This was also motivated by the fact that a great number of young people were migrating to Gauteng from Limpopo, as well as other parts of South Africa, in order to study at the universities, technical colleges and other institutions located in Gauteng. Others found their respective ways to cities such as Pretoria and Johannesburg to find work. Besides the youth, many adult men and women also migrated to these and other big cities in Gauteng in search of employment. This created a huge opportunity for the church in terms of mission.

After the conference, Prof. Rabali was requested to write a booklet about the teachings he delivered at Tshipise, which, when published, was entitled Tshivhumbeo tshashu sa Kereke ri tshi pfuka nwaha wa 2000 (Rabali 1998). The booklet was widely read and discussed and had a great impact on the leadership of the church, as well as on the church members of

1.The leadership conference was attended by church council members from the following Reformed congregations: De Hoop, Hosiyata, Malamulele, Mutale, Niani, Soutpansberg, Nzhelele, Tshitandani, as well as from Reformed Church Tshiawelo. 
the Synod Soutpansberg. The content of the book addressed many of the issues the churches had to face and inspired them to accept responsibility for the mission of the Church in the city. The same happened to the church leaders and church members of the RCT, who were equally persuaded by the booklet to open their minds to the necessity and urgency of urban mission in Gauteng Province. During the same year (1998), the Synod Soutpansberg, at its regular meeting held at the Iyani Bible and Training Institute, Sibasa, took a decision to initiate an urban church planting project in Gauteng. In most of the meetings of the Synod Soutpansberg in years to come, the matter of urban mission continued to stay high on the agenda. According to the Acts of the Synod Soutpansberg of the Reformed Churches in South Africa (RCSA 2000:8), the second mandate of the mission deputies of Synod Soutpansberg was to keep looking for a place where urban mission should be carried out in South Africa - especially in Gauteng. The mission deputies, in their report to the Synod held in December 2000 at Iyani Bible and Training Institute, indicated that they had contacted Prof. Rabali concerning the mission work in Tshiawelo, Pretoria and Johannesburg, where newly founded churches were growing tremendously (RCSA 2000:9).

\section{Partnership in the training of ministers}

In the development of the mission of the RCT, the Heidelberg Theological Seminary, the official training institution of the Synod Soutpansberg, had an important role to play. The lecturers helped the students to understand the church's mission, as well as their own responsibility, once they were to be ordained and sent out by the church. In turn, the reports of what had happened in Tshiawelo informed the curriculum of the seminary. In terms of what is happening across the globe, this was to be expected. According to Kritzinger, Meiring and Saayman (1984:6), the partnership between churches in the theological training of students is very essential, especially in the case of theological seminaries which had originated as a result of the missionary work of the church. Kirk (1999) is of the opinion that:

There can be no theology without mission - or, to put it another way, no theology which is not missionary. This is partly a matter of observation in that theology is, by its nature, about fundamental concerns which affect life at all levels. People engaged in theological reflection invariably take up positions on a whole host of important matters, even if they do so from vastly different stances, with conflicting results and sometimes without being aware of what they are doing. Theology, even when it claims to be nonpartisan, is in reality thoroughly committed, as has so often been pointed out in recent years. In countless respects, it is in the business of persuading others to believe and act in specific ways. The missionary nature of theology is unavoidable. (p. 11)

\section{Rebuilding the congregation of Tshiawelo}

In the process of building and strengthening the congregation of Tshiawelo, a series of practical steps were taken. These will be explained in the following subsections.

\section{Leadership training}

Equipping the laity for urban ministry begins with the vision of the minister and the leadership. The leadership of this congregation had a commitment to mobilise the church for worship, for proclaiming the Word of God and for her mission to the world. Neil Braun (1971:140) reminds us that if churches are to move into an era of church multiplication based primarily upon evangelism, the training of the laity must be assigned as a high priority as well. Men, women and the youth are to be recruited, equipped and encouraged to identify and penetrate their respective worlds with the Gospel (Bakke 1997:91). Urban lay people stand at the centre of four distinct 'worlds' in their primary relationships - the worlds of family (biological), neighbours (geographical), work (vocational) and play (recreational) (Bakke 1997:91) and should be equipped to serve as witnesses of Christ in these worlds. Leadership that follows the instructions of the Bible brings the church to maturity and to service.

In the city, as in other places, a vision for the renewal is needed. When Prof. Rabali started to work in the RCT congregation, he proceeded to equip and motivate leaders for their missionary calling, explaining to them that the most important aspect of their training was not only theoretical teaching, but practical exposure. The leaders were therefore taken along when house visits were undertaken by Prof. Rabali (cf. Mutavhatsindi 2000:37). Mentoring the leadership was of the utmost importance to Prof. Rabali, who encouraged them to use the spiritual gifts which God entrusted to them. The importance of this is underlined by Conn and Ortiz (2001) in their seminal book on urban ministry:

It is wise to mentor people in the use of their particular gifts as part of the training component. Mentoring assists the growth of the individual but also provides accountability. Churches should keep in mind that there are areas of ministry in which all Christians should be involved, such as giving, teaching and evangelism, and that training should also provide for those areas of service. (p. 465)

In order to equip and empower the leaders and laity in the church, Prof. Rabali wrote down his sermons and teachings for their perusal. He also published two books to help in the process: Nga vhudele na nga Mulayo (Rabali 1993) and Khuvhangano ya Nyambedzano dza vhafunzi (Rabali 2005a).

\section{Sunday preaching}

Preaching is one of the most important tools to change the hearts of people. Through preaching, one can lead people to a spiritually bright future. This, too, happened in the life of the RCT. On Sundays, the minister's enthusiastic preaching drew many to attend the church. He prepared his messages in such a way that through his preaching, God touched the hearts of the people and brought changes to their lives. This is what the preaching should do: it must change peoples' hearts, their lifestyle and also their behaviour. When Prof. Rabali preached the Word of God, the congregation realised that although he was talking from his own experience, the message was not his. It was God's message, delivered in a language that everybody understood. When he stood in the 
pulpit, he preached as a man who was given a last chance to preach, who would no longer get the opportunity to stand on the pulpit again. He gave himself ample time for preparation - and also for preaching during the service. All this indicated that preaching in this congregation was regarded as extremely important. It inspired the congregants, impacting on the missionary élan of the members of the church.

\section{House visitation}

A missionary church should inspire its members to be committed to and involved in evangelistic visitation. These members do not only invite others to attend Sunday services, they try to lead lost persons to Christ, even before they can be persuaded to visit the church for the first time. In the case of the RCT, a group of committed and experienced members were active in the regular visitation programme of the church and in specialised evangelistic programmes, such as Evangelism Explosion or Continuing Witness Training. Even more effectively, they served as agents of growth through their everyday activities. As sharing their faith in Christ became a normal part of their lives, they reached out to their friends, family members, co-workers and acquaintances, sharing, also, their love for Christ with them (Hadaway 1991:31). House visitation became a priority to the elders and deacons of the church. Professor Rabali continuously encouraged them to bear their responsibilities, often repeating to them, especially when things were tough: Kha ri kondelele, zwidoluga, which means 'Let us persevere, it will be fine'. He also stressed the importance of house visitation in his book, Nga Vhudele na nga Mulayo (cf. Rabali 1993:16-28). House visits usually occurred on Saturdays and holidays. Special attention was given to visiting those who were attending Sunday services for a first time. Thus, the RCT had discovered the truth of Hadaway's (1991) insights:

The concept of visitation should be expanded beyond showing up at someone's front door for an appointment or an unannounced visit. In fact, in an urban setting, meeting someone for lunch may be more appropriate than visiting them at home. Similarly, talking to homeless persons on a street corner or making a point to talk to an unchurched friend during a break at work, at the health club, at the grocery store, over coffee, or across the back fence can be, and should be, seen as prospect visitation. Prospect visitation is more difficult in some settings than in others, but in any setting, greater success results from visiting prospects that are already linked to the church or to church members in some way. Clearly, the best prospects are those who have already visited the church. If a church is not visiting these persons, it is literally begging to decline. Churches which have few visitors should start with those they do have and develop ways to attract others. Various forms of social ministry can all be used to draw visitors and develop a list of viable prospects. The names are wasted, however, if they are not followed up quickly. (pp. 24-25)

\section{Catechism classes}

The church leaders of the RCT congregation realised that for people to grow in faith, and to acquire a deeper knowledge of the Bible as well as of Reformed doctrine, they needed proper instruction. In the RCT, men and women who attended the church for the first time, and who were unable to profess their faith, were encouraged to regularly attend the catechetical classes. The first author's research showed that these newcomers enjoyed the membership classes (catechism classes) and found them to be very effective, enabling them to become committed and active members themselves. Those in catechism class were taught the Heidelberg Catechism and Reformed doctrine. The teachers who presented the catechism classes were, themselves, instructed regularly as well, in order to conduct the classes to the best of their ability. After careful examination, the members of the catechism class were baptised and invited to become active members of this congregation.

\section{Mission seminars and conferences}

One of the mandates entrusted to the mission deputies of the Synod Soutpansberg by was to organise urban mission workshops and conferences focusing on Gauteng Province (RCSA 2005b:20). This mandate was carried out by the Synod's deputies for mission in cooperation with the church council of the RCT and, over the years, the RCT held three mission conferences per annum. The primary purposes of such mission conferences were to develop the church's mission vision, to motivate congregants for mission, as well as to share experiences on how to be witnesses of Christ especially in urban areas. Over and above these regular local church mission conferences, they also conducted a number of urban mission seminars and conferences to which they invited the churches from the Soutpansberg area, their partners in mission. Such mission conferences were held in 2000 at Tshiawelo, in 2003 at Tshiawelo, in 2005 in Johannesburg and in 2007 in Pretoria. The primary aim of these four major urban mission conferences was to clarify the different churches' vision, plans and objectives, as well as to advance and motivate a passion for urban mission amongst leaders and congregants.

The content of the seminars and meetings revolved around the necessity to persuade the church members to accept their responsibility of preaching Christ as the only saviour, the Lord who came to this world to reconcile the world with God so that those who repent may receive eternal life. God did this because he loves us (Jn 3:16). The eyes of the church members needed to be opened to recognise their responsibility to the Great Commission, by making people disciples of our Lord Jesus Christ (Mt 28:19-20). The church members needed to understand that the scope of our mission is unlimited and that they are called to witness Christ within their own communities, as well as to their neighbouring areas and also to the other parts of the world (Ac 1:8). The importance of partnering with the Soutpansberg churches with respect to urban church planting was often stressed. Professor Rabali, again, played a huge role during these conferences and workshops. Some of his teachings are included in his book on mission, Vhurumiwa na Doroboni-vho! (see Rabali 2005b).

\section{Small groups}

Another method utilised in order to rebuild the RCT, was to organise and coordinate small groups in the congregation. 
Cell groups met in some of the wards during the week. Others met on Sundays when men, women and young people came together for study and prayer. Some of the fellowship centres organised their own cell groups as well, rotating visits to the homes of church members (Hadaway, Dubose \& Wright 1987:230). The regular programmes included Bible studies, singing, topical discussions, et cetera. The members of these groups testified that they enjoyed the fellowship with one another and that the meetings served them well. They empowered and encouraged one another. What happened to them, happened to other churches across the globe as well. In this regard, the American missiologist J.T. Young (1978) reported from his own experience:

A great church is one which has a good fellowship among its members. It gives a living demonstration that the essential nature of a church is a fellowship in Christ. This kind of fellowship is essential for any church to experience a degree of success. With this fellowship almost any obstacle can be overcome. Without this fellowship the church is severely handicapped, if not doomed. (p. 38)

Small groups proved to be a good place to begin and to continue the process of training. It was in the small groups that members become involved with the needs of the community, as people shared their concerns (Conn \& Ortiz 2001:466). The fellowship of church members was based on their fellowship with Christ. Just as there is a bond of love between the individual believer and his Lord, a similar bond of love unites believer with believer. A Christian's experience of salvation is essentially a relationship of love which expresses itself vertically, between the believer and Christ, and horizontally, between the believer and his fellow believers (Young 1978:38). This is what members of the RCT were experiencing. Visitors in the church, as well as those who observed what had happened from a distance, were impressed by the demonstration of mutual love and by the spirit that they saw amongst the church members (Young 1978:39).

\section{Targeting groups of people in the city}

The RCT targeted various groups of people in Johannesburg and Pretoria. The first targeted group was the people who migrated from rural areas to urban areas, especially those who came from churches that belonged to the Synod Soutpansberg. Amongst them were those who came looking for jobs, as well as students who arrived with the hope to study at the educational institutions that are found in Gauteng. Another priority was to target the various groups of volunteers in the church, empowering them with proper teaching and practical training. Another target group was the unbelievers in the area who were often encountered during mission campaigns. This helped the RCT to progress in her mission endeavours. According to Müller (1987:35), a church that is not missionary, a church that does not reach beyond itself, transcending itself in the process, is no real church.

\section{Mission campaigns}

During the first author's research, both the church members and church leaders emphasised the importance of following mission conferences with mission campaigns.
The congregation needed to be equipped and motivated to involve themselves in urban mission. From time to time, they were joined by fellow Christians from the Reformed Churches in the Soutpansberg area. The transport costs were carried by the RCT. Working together strengthened and also broadened both the partnership and the relationship between the RCT and churches that constitute the Synod Soutpansberg.

\section{The growth of the church and the planting of new daughter churches}

As stated above, the RCT was established by missionaries in 1968, but her growth was slow and painful. During the 1970s and 1980s, the church membership was actually in decline. Some church members moved to other churches, whilst others elected to go nowhere - but preferred to stay at home. The few people who did remain were discouraged and pessimistic about the future, despairing that the church could ever be rebuilt and flourish again. This was confirmed by Mrs Phampha, who grew up in this congregation from childhood and who attended Sunday school, youth activities, and other church activities at this congregation. Mrs Phampha spoke of her experiences on 16 August 2008 at the RCT during the celebration of this congregation's 40th anniversary. At the same meeting, Mutheiwana George, who served in this congregation in the office of elder for many years, and who was still serving in this office in 2008 , told of the painful period when membership was in decline. He, too, was in despair and lost all hope that the RCT would be rebuilt.

But God in his grace brought new life to the church and new churches were planted in a specific way. Amongst the members of the RCT, a group of core leaders were identified and trained to engage in mission work in the local area (Tshiawelo). In addition, a number of students from Soutpansberg arrived on the scene, to strengthen the ranks of the RCT. These students were staying in different places: in the Vaal area, in Protea Glen, Pretoria, Johannesburg, as well as Midrand. Together with the church members of the $\mathrm{RCT}$, they were trained to propagate the Word of God and also to conduct small groups' services in their areas. The church council, in her strategic planning, resolved to start worshiping centres by forming small groups' services in the areas where those few students were staying, with the aim of developing these worshiping services into new churches. This is exactly what happened and, by 2008, these small groups' services in the different locations had developed into proper congregations. The decline that had been experienced up to the early 1990s was thus reversed and the RCT started to grow once more.

Looking back, the process of the rebuilding of the church can be subdivided into two periods: 1995-2001 and 2002-2008, when a peak was reached with the establishment of the new worshipping service centres, the planting of new daughter churches and the constituting of a new classis of Synod Soutpansberg in Gauteng. This new classis was constituted by RCT and her daughter churches on the 16 August 2008, at the 40th anniversary of the Tshiawelo congregation. 
In 1995, the church membership was indeed very small. Although a few men and women who had migrated to urban areas in Gauteng had joined the RCT, there was no significant change in the membership of the church. Indeed, the church during this year had less than 30 members. But then Prof. Rabali and a number of church council members joined forces. They worked hard, strengthening the existent congregants, as well as reaching out to a growing number of migrants from churches that constituted Synod Soutpansberg, who came to the area. In addition, the RCT also reached out to un-churched people in the area, young and old, inviting them into the fellowship of the congregation. By 1997, the flow of young people who came to study at institutions in Gauteng had increased. Most of the students who associated themselves with this church were equipped to become mission-minded members and some of them were trained to be church leaders. Young men who showed commitment in church activities were ordained as church council members, after they had undergone training. At the RCT's 30th anniversary held at Tshiawelo in 1998, the vision of establishing new fellowship centres outside Soweto was embraced by the church council. In 1998, the members of a Tuesday evening Bible study and prayer cell group that took place in a flat in Pretoria had begun to worship at Tshiawelo on Sundays. The church council subsequently transformed this group into a fellowship centre, with Sunday services and midweek meetings by 1999. During this year, the number of migrants, students and elderly people who came to work in Gauteng, and who associated themselves with RCT, had increased even more. Many men and women travelled between Johannesburg and Pretoria by train, taxi and also by car to attend worship services. Recognising the great number of people who attended services in Tshiawelo, the church council established a new fellowship centre in Johannesburg in the year 2000. During that same year, the church council organised an urban mission seminar at Tshiawelo which was well attended by people from different areas. Churches that constituted the Synod Soutpansberg sent delegates in great numbers to attend this event. In 2001, the church continued to grow to such an extent that the RCT church council decided to establish a new fellowship centre in Protea Glen.

During the period 2002-2008, the church continued to grow spiritually as well as in numbers. The regular mission conferences, preaching and home visits contributed to the new life in the RCT. In 2003, the church established a new fellowship centre in Midrand. During this year, the church council organised an urban mission conference at Tshiawelo and Christians were inspired and encouraged to engage themselves in urban mission. In 2004, two new fellowship centres were established, one in Katlehong and the other in the Vaal region. During the same year, the church celebrated the 5th anniversary of her fellowship centre in Pretoria. In 2005, the church had two more anniversary ceremonies, in celebration of the 5th anniversary of the two fellowships centres in Johannesburg and Dube. During that same year (2005), there was an urban mission conference that was held in Johannesburg. In 2006, a new fellowship centre was established in Muldersdrift, whilst in 2007, two additional fellowship centres were established, one in Meadowlands and the other in Middelburg (Mpumalanga Province). The centre in Meadowlands was established after Classis Moroka indicated to the RCT that, because the RCT was no longer one of the churches that constitute this Classis, RCT must no longer use the church building of Dube, which was under this Classis. The RCT then started a fellowship centre in Meadowlands and many of the church members that used to worship at the church building of Dube, moved to Meadowlands. Also during 2007, there was an urban mission conference in Pretoria.

The RCT reached her peak during her 40th anniversary conference which was held in Tshiawelo on 15-17 August 2008. This celebration was well attended by members from the Synod Soutpansberg, some members from the Madison Avenue Christian Reformed Church (USA) and members from the local churches. The growth rate of the RCT was indeed spectacular. In 1995, it had less than 30 members, but in 2008 her members were more than 1000. In his message to the 40th anniversary conference, Prof. Rabali preached from Isaiah 54, encouraging the church members to accept the necessity of planting churches in South African cities and those across Africa, as well as indicating the great possibilities of reaching even European countries with the Gospel of the Lord Jesus Christ. They were encouraged to extend the scope of their mission, 'Enlarge the place of your tent, stretch your tent curtains wide, do not hold back; lengthen your cords, strengthen your stakes' (Is 54:2, New International Version [NIV]). The culmination of this celebration was on 16 August 2008, when the RCT planted five new daughter churches at the same time: Reformed Church Vaal, Reformed Church Protea Glen, Reformed Church Pretoria, Reformed Church Midrand and Reformed Church Johannesburg. After planting these daughter churches, a new classis (Classis Gauteng) of the Synod Soutpansberg was constituted the same day, comprising the RCT and her five daughter churches. This was a blessing to the Synod Soutpansberg, which is now comprises three Classis, namely the Classis Gauteng, as mentioned above, the Classis Gateway ${ }^{2}$ and the Classis Luvuvhu ${ }^{3}$.

\section{The future plans for the church}

From the research conducted by the first author, it is clear that the RCT, after a slow start, had become a church with a promising future, heavily involving itself in urban mission. In the Synod Soutpansberg, the RCT had grown into a symbol of hope. Moreover, the RCT had decided to cast its net even further. Other urban areas therefore had to be considered. Many people were moving to the metropolitan areas of Durban, Cape Town, Bloemfontein, Port Elizabeth

2.Classis Gateway comprises the following churches: Reformed Church Fundudzi, Reformed Church Nzhelele, Reformed Church Seshego and Reformed Church Tshitandani.

3.Classis Luvuvhu comprises the following churches: Reformed Church De-Hoop, Reformed Church Hosiyata, Reformed Church Mutale and Reformed Church Niani. 
and Kimberley, some again, in search of work, and others in need of education. New opportunities presented themselves and the Tshiawelo leadership readily confessed that they had been speaking about planting churches in other South African metropolitan cities for a long time, but that not much had been done to date. In 2007, they were able to establish the first fellowship centre outside the Gauteng Province, in Middelburg (Mpumalanga), but this needed to be followed with projects in the other cities of South Africa. What needed to be done was that RCT had to formulate a strategy to reach these new areas (Patterson 1989:22).

\section{Conclusion}

From the research outlined in this article, it is evident that the RCT had become one of the churches within the Reformed family in South Africa that is making its mark in the field of urban mission. It is equally clear that the leadership of Prof. T.C. Rabali, together with his co-workers, played an important role in bringing the church to her present stage. Christians were taught, motivated and involved in mission work. Looking back, there is much to be grateful for. God has been gracious and kind to the men and women from Tshiawelo. But now the future awaits the congregation and its leadership. There is more work to be accomplished. There are still many areas of concern in the mission of the RCT that requires serious attention. May the Lord Jesus who has called his followers to make disciples of all the nations upon the earth (Mt 28:19), empower the people from Tshiawelo to be faithful to their calling.

\section{Acknowledgements Competing interests}

The authors declare that they have no financial or personal relationships that may have inappropriately influenced them in writing this article.

\section{Authors' contributions}

The article is based on research conducted by M.A.M. (University of Pretoria) for his PhD thesis. P.G.J.M. (University of Pretoria), co-author of the article, acted as supervisor for the thesis.

\section{References}

Bakke, R., 1997, 'The challenge of world evangelization to misson strategy', in H.M. Conn (ed.), Planting and growing urban churches: From dream to reality, $\mathrm{pp}$. 79-83, Baker Books, Grand Rapids. PMid:9281355

Braun, N., 1971, Laity mobilized: Reflections on church growth in Japan and other lands, Eerdmans, Grand Rapids.

Conn, H.M. \& Ortiz, M., 2001, Urban ministry, InterVarsity Press, Downers Grove.

Hadaway, C.K., 1991, Church growth principles. Separating fact from fiction, Broadman Press, Nashville.

Hadaway, C.K., Dubose, F.M. \& Wright, S.A., 1987, Home cell groups and house churches, Broadman Press, Nashville.

Kirk, J.A., 1999, What is mission? Theological explorations, Darton, Longman and Todd, London.

Kritzinger, J.J., Meiring, P.G.J. \& Saayman, W.A. (eds.), 1984, You will be my itnesses. An introduction to methods of mission, NGKB, Pretoria.

Müller, K., 1987, Mission theology: An introduction, Studia Instituti Missioliogici Societatis Verbi Divini, Sankt Augustine.

Mutavhatsindi, M.A., 2000, 'On being a responsible witness of Christ in the world with special reference to the Reformed Churches in Venda', unpublished MTh dissertation, Department of Missiology, University of Potchefstroom.

Mutavahdsindi, A.M., 2008, 'Church planting in the South African urban context, with special reference to the Reformed Church Tshiawelo', PhD dissertation, Department of Science of Religion and Missiology, University of Pretoria.

Patterson, G., 1989, Church planting through obedience-oriented teaching, William Carey Library, Pasadena.

Rabali, T.C., 1993, Nga Vhudele na nga Mulayo. Zwine Bivhili ya Funza nga ha Kereke, Kuvhuselwe na Kutshimbidzelwe kwayo, Sunsetview Publishers, Vanderbijlpark.

Rabali, T.C., 1998, Tshivhumbeo tshashu sa Kereke ri tshi pfuka Nwaha wa 2000, Iyani Bible and Training Institute, Sibasa.

Rabali, T.C., 2005a, Khuvhanganyo ya Nyambedzano dza Vhafunzi, Iyani Bible and Training Institute, Sibasa.

Rabali, T.C., 2005b, Vhurumiwa na Doroboni-vho, Plantinum Press, Vanderbijlpark.

Reformed Churches in South Africa, 2000, Acts of Synod Soutpansberg of the Reformed Churches in South Africa, 28-30 March, Sibasa.

Reformed Churches in South Africa, 2005a, Die Almanak van Die Gereformeerde Kerke in Suid-Afrika, RCSA, Potchefstroom.

Reformed Churches in South Africa, 2005b, Acts of Synod Soutpansberg of the Reformed Churches in South Africa, 08-10 December, Sibasa.

Young, J.T., 1978, The Church - Alive and growing, Broadman Press, Nashville. 